\title{
Selection of resistant rootstocks to Meloidogyne enterolobii and M. incognita for okra (Abelmoschus esculentus L. Moench)
}

\author{
Marcus Vinícius Marin ${ }^{1 *}$, Lucas S. Santos ${ }^{1}$, Lucas A. Gaion ${ }^{1}$, Hudson Rabelo ${ }^{1}$, \\ Carolina A. Franco ${ }^{1}$, Guilherme M. Diniz ${ }^{1}$, Edgard H.C. Silva ${ }^{1}$, and Leila T. Braz ${ }^{1}$
}

\section{ABSTRACT}

The okra (Abelmoschus esculentus L. Moench) is one of the most important vegetables in the world and is a popular food item in many tropical and subtropical countries. Besides its cultivation for fresh consumption, okra also has potential industrial uses. Nonetheless, pests and diseases remain the most damaging factors affecting its crop yield. Among these, root-knot nematodes are the main pests limiting okra production. This study aimed to determine the responses of plant species of the Malvaceae family to Meloidogyne incognita and M. enterolobii rootknot nematodes, and to also assess the compatibility of the same with the okra commercial 'Colhe Bem IAC'. Resistance was evaluated using the reproduction factor in two commercial okra cultivars ('Colhe Bem IAC' and 'Santa Cruz 47'), five cotton (Gossypium hirsutum L.) plant genotypes (PRO 277, IAC 29-233, PR 136, IAC 24, and IAC 03-979), and vinagreira (Hibiscus sabdariffa L.) Other resistance-related traits measured were the percentage of healing, plant height, root length, rootstock stem diameter, scion stem diameter, number of leaves, total fresh weight, and fresh weight of the scion, rootstock, and root parts. While the cotton and vinagreira genotypes tested were resistant to both species of nematodes, okra cultivars were not. The okra, however, showed successful adaptation to grafting, which may offer an important physical resistance against attacks by root-knot nematodes, while vinagreira showed the greatest potential for use as rootstock for protecting okra crops.

Key words: Gossypium hirsutum, grafting, nematode, plant parasites, root-knot, scion.

${ }^{1}$ Universidade Estadual Paulista, Via de Acesso Prof. Paulo Donato Castellane, Jaboticabal, SP 14884-900, Brasil.

"Corresponding author (marcusvmarin@gmail.com).

Received: 2 October 2016.

Accepted: 17 January 2017.

doi:10.4067/S0718-58392017000100007.

\section{INTRODUCTION}

The okra plant (Abelmoschus esculentus L. Moench) is one of the most important vegetables in the world, especially in the tropical and subtropical regions. Although grown mainly for human consumption, okra has also attracted recent interest as an industrial source of fiber. Furthermore, okra seeds provide high quality oil, and the mucilage from its fruit contains carbohydrates and pectin that can be used as a thickener in the food industry (Alegbejo et al., 2008).

The most damaging factors to an okra crop are diseases and pests. Among these, root-knot nematodes (Meloidogyne spp.) are the most harmful to okra production (Hussain et al., 2011). They are considered one of the five major enemies of plants worldwide, and rank as one of the 10 most important genera of nematodes globally (Kayani et al., 2013).

These nematodes, however, pose the greatest problem for crops in the region of the tropics, since the environmental conditions there are favorable for their infection, development, and reproduction (Hussain et al., 2012).

Plants affected by nematodes show slow growth, leaf yellowing, and wilting, and limited root development. Galls develop in the infected roots from the formation of giant cells used by this parasitoid as a source of nutrients. These modified cells can interfere with the flow of water and nutrients within plants, resulting in crop yield reductions or even the total loss of the crop (Daramola et al., 2015). Hussain et al. (2011) found that an impaired development of okra was directly proportional to the initial nematode population density, yet inversely proportional to the age of the plant. In addition, through the damage they cause, these parasites can interact synergistically with other diseases or breakdown genetic resistance to other enemies, and further reduce plant tolerance of environmental stress (Begum et al., 2012).

In an assessment of the prevalence, incidence, and severity of nematode attack in okra-planted areas in Pakistan, very harmful effects were caused by species of the Meloidogyne genus, of which $M$. incognita was the most important (Hussain et al., 2012). Similarly, Oliveira et al. (2007) evaluated the nematode fauna associated with an okra crop, in the State of Minas Gerais, Brazil, and were alerted to the occurrence of M. enterolobii. This nematode causes such considerable losses in the production of okra that infected cultivated areas are often soon abandoned (Carneiro et al., 2001). 
Due to the widespread risk from nematodes, several researchers have evaluated the reaction of okra cultivars to root-knot nematodes. However, there are no reports yet of the existence of completely resistant cultivars, only those of moderate resistance and susceptibility (Mohanta and Mohanty, 2012; Hussain et al., 2014).

Chemical control to reduce nematode impact on okra is not favored by farmers and consumers because of its high cost, toxicity, and low efficiency. Also unfeasible is trying to use resistant cultivars that lack proven resistance in the okra to Meloidogyne spp. Therefore, the grafting of commercial cultivars is an alternative tool that could be used to manage the impact of nematodes.

Grafting has proven effective at controlling diseases caused by soil-borne pathogens, and for providing tolerance to abiotic stresses, such as high/low temperatures, salinity, drought or flooding, and toxicity from heavy metals (Louws et al., 2010; Fallik and Ilic, 2015). However, this technique requires specialized procedures, a high initial cost, and a longer time for the treated seedlings to reach the stage of transplanting. Nevertheless, in its favor, are the improved cost/benefit ratio, increased productivity, longer harvest period, and the possibility of intensive cultivation in the same area, which together now make grafting economically viable.

Grafting in okra is a little technical untapped, however, considering the existence of robots to execute this technique, it may be employed in the management of culture. The robot model developed in Japan to cucurbits is equipped with cup feeders and rootstocks, which capture and direct the parties to the grafting, carrying 750 grafts per hour, with an average rate of fixation of $90 \%$, with only one trained worker for inspection. Another fully automated model was developed in the Netherlands and can engraft 1000 seedlings of tomato (Solanum lycopersicum L.) or eggplant (S. melongena L.) per hour, with more functions, such as automatically select matching rootstock and canopy crucial process to increase the success rate (Kobayashi, 2005). ISO Graft 1200 (ISO Group, Gameren, The Netherlands) equipment ensures $99 \%$ set in the grafting with the ability to engraft 1000 plants per hour (ISO Group, 2014).

Our study was spurred by the shortcomings of chemical control, lack of sources of resistance in okra cultivars, and the few grafting studies. In particular, it is crucial to identify resistant genotypes in species taxonomically close to okra, as this is a requirement for compatibility in the grafting approach to resistance (Goldschmidt, 2014).

Thus, the pattern of knowledge of reaction to the nematode-of-galls on Malvaceae family species grafting compatible with okra and the use of robots, can help to develop new management strategies of these pathogens.

Therefore this study aimed to determine the responses of plant species of the Malvaceae family to the root-knot nematodes, $M$. incognita and $M$. enterolobii; and to assess the same for their compatibility with a commercial okra cultivar.

\section{MATERIAL AND METHODS}

Two experiments were conducted in a greenhouse in

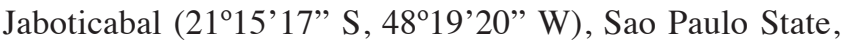
Brazil, to study the feasibility of grafting on okra plants. In the first, we evaluated two commercial cultivars of okra ('Colhe Bem IAC' and 'Santa Cruz 47'), five cotton genotypes (PRO 277, IAC 29-233, PR 136, IAC 24, and IAC 03-979), and vinagreira (Hibiscus sabdariffa L.) for their resistance to Meloidogyne enterolobii and $M$. incognita. The tomato 'Santa Cruz Kada' was used as a control for inoculum viability. The eight treatments were arranged in a randomized design with eight replicates, and each replicate represented by one vase containing one plant. This experiment was repeated once again to confirm resistance of the genotypes.

Seeds of different genotypes were sown in polystyrene trays of 128 cells filled with commercial substrate, mixture of pine bark and coconut fiber (Bioplant, Nova Ponte, Minas Gerais, Brazil). After appearance of the first true leaf, seedlings were transplanted to $5 \mathrm{~L}$ pots containing previously autoclaved mixture of earth, bovine manure, and sand (3:1:1, respectively). Two days after transplanting, plants were inoculated with 5000 eggs and second-stage juveniles of M. incognita and M. enterolobii (separately).

Exactly $60 \mathrm{~d}$ after transplanting, nematodes were removed from plants. To do this, the roots of each plant were washed with water and grinded in a solution of $0.5 \%$ sodium hypochlorite. The counting of the extracted eggs and juveniles was performed in a Peters chamber (Astel, model M) aided by an optical microscope.

The resistance of each plant genotype was measured using the reproduction factor (FR), which is the ratio of the initial to final population of the nematodes. It was adopted following the recommendation of Oostenbrink (1966) to qualitatively define the plant response pattern: cases with FR $<1$ or FR $>1$ were considered resistant or susceptible, respectively.

Figure 1. Temperature values (maximum, mean and minimum), and relative humidity during the experimental period in the humidity chamber.

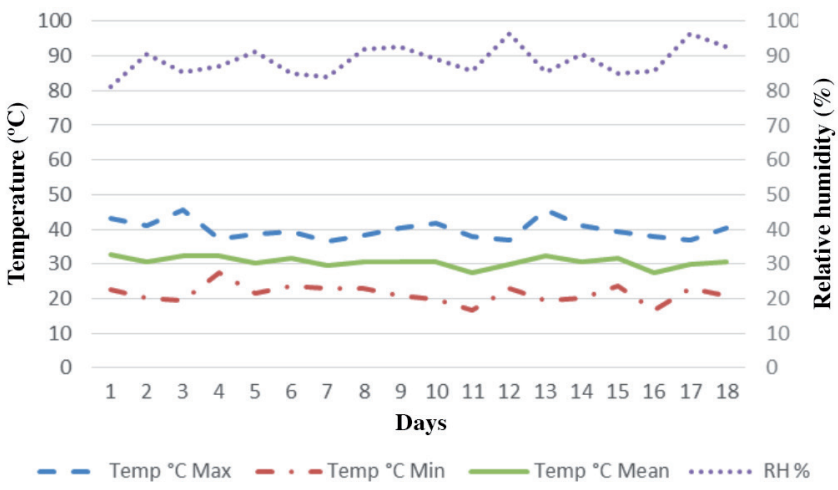


In the second experiment, the genotypes considered 'resistant' were used as rootstocks for grafting with okra 'Colhe Bem IAC', in order to study their compatibility levels. Here, a completely randomized design was again used, but with 10 replicates (one plant per pot). The seedlings of the genotypes were obtained as mentioned above, and each was transplanted into $250-\mathrm{mL}$ plastic cups filled with Bioplant commercial substrate, moments before grafting. We used the cleft grafting method as described by Yamakawa (1982). Throughout the experimental period, plants were kept at high humidity in a growth chamber monitored for temperature and humidity (Figure 1).

The surviving percentage of grafted seedlings was determined $17 \mathrm{~d}$ after grafting. Survival was restricted to those plants with complete healing of the graft region. To this, it was adopted the randomized block design with 10 replicates, each portion consisting of 10 plants.

On the day of grafting, we measured plant height (ALT), rootstock diameter (DPE), and scion diameter (DE). After $18 \mathrm{~d}$ of grafting, characteristics of plant development associated with nematode resistance were evaluated by remeasuring ALT, DE, and DPE; by counting leaves number (NF); and by quantifying total fresh weight (MFT), scion fresh weight (MFE), rootstock fresh weight (MFPE) and root fresh weight (MFR). The results were submitted to separate one-way ANOVAs and the treatment means were compared by the Tukey test at a 5\% significance level, using the GENES program.

\section{RESULTS AND DISCUSSION}

Genotypes differed significantly in their response to the presence of root-knot nematodes. For example, 'Santa
Cruz 47' and 'Colhe Bem IAC' were susceptible to both species of nematodes, each plant having reproduction factor (FR) values of 2.63 and 2.23 to M. enterolobii and 1.12 and 1.10 to $M$. incognita, respectively (Table 1 ). The remaining genotypes were all resistant to both species of nematodes (FRs $<1.0$ ). As M. enterolobii is the most aggressive species, it elicited the largest FR values in all plant genotypes.

The search for resistant varieties is extremely valuable to the crop grower, since it is a mean for sustainable production and mitigates the production costs. Hussain et al. (2014) evaluated the behavior of okra cultivars to a root-knot nematode; they found no evidence of resistance to this parasite, which was associated with significant reductions in the fresh and dry weight of shoots but an increase in root growth due the formation of galls. Several other researchers have evaluated the reaction of okra cultivars to nematodes, but a resistant cultivar is yet to be found (Mohanta and Mohanty, 2012; Hussain et al., 2014).

Although crop rotation with non-host plants coupled to the use of chemicals could be effective for controlling nematodes, genetic resistance remains the preferred strategy because it is a more sustainable tool (Louws et al., 2010), and also enables intensive cultivation. Furthermore, resistance is routinely incorporated into commercial cultivars, genetically or via resistant rootstocks.

The use of resistant genotypes can suppress the population of nematodes in a given area more effectively than the use of chemicals. Rivard et al. (2010) observed that in an area under high pressure from M. incognita, nongrafted tomatoes were severely damaged. These authors evaluated three rootstocks for tomato and observed that 'Maxifort' and 'Beaufort' had low incidence of galls

Table 1. Responses of the Malvaceae plant genotypes to root-knot nematodes (Meloidogyne enterolobii and M. incognita). UNESPFCAV, Jaboticabal, São Paulo, 2015.

\begin{tabular}{|c|c|c|c|c|c|c|c|c|}
\hline \multirow[b]{2}{*}{ Genotypes } & \multirow[b]{2}{*}{ Species } & \multirow[b]{2}{*}{ PI } & \multicolumn{3}{|c|}{ Resistance evaluation } & \multicolumn{3}{|c|}{ Resistance confirmation } \\
\hline & & & PF1 & FR1 & Reaction 1 & PF2 & FR2 & Reaction 2 \\
\hline \multicolumn{9}{|c|}{ Meloidogyne enterolobii } \\
\hline $\mathrm{St}^{\mathrm{a}}$ Cruz kada & Tomato & 5.000 & 150.200 & 30.04 & $\mathrm{~S}$ & 150.450 & 30.09 & $\mathrm{~S}$ \\
\hline Colhe Bem & Okra & 5.000 & 13.350 & 2.67 & $\mathrm{~S}$ & 13.150 & 2.63 & $\mathrm{~S}$ \\
\hline Santa Cruz 47 & Okra & 5.000 & 11.500 & 2.30 & $\mathrm{~S}$ & 11.150 & 2.23 & $\mathrm{~S}$ \\
\hline PRO 277 & Cotton & 5.000 & 1.750 & 0.35 & $\mathrm{R}$ & 1.700 & 0.34 & $\mathrm{R}$ \\
\hline IAC 29-233 & Cotton & 5.000 & 750 & 0.15 & $\mathrm{R}$ & 850 & 0.17 & $\mathrm{R}$ \\
\hline PR 136 & Cotton & 5.000 & 700 & 0.14 & $\mathrm{R}$ & 700 & 0.14 & $\mathrm{R}$ \\
\hline Vinagreira & Vinagreira & 5.000 & 700 & 0.14 & $\mathrm{R}$ & 650 & 0.13 & $\mathrm{R}$ \\
\hline IAC 24 & Cotton & 5.000 & 400 & 0.08 & $\mathrm{R}$ & 250 & 0.05 & $\mathrm{R}$ \\
\hline IAC 03-979 & Cotton & 5.000 & 250 & 0.05 & $\mathrm{R}$ & 150 & 0.03 & $\mathrm{R}$ \\
\hline \multicolumn{9}{|c|}{ Meloidogyne incognita } \\
\hline $\mathrm{St}^{\mathrm{a}}$ Cruz kada & Tomato & 5.000 & 101.000 & 20.20 & $\mathrm{~S}$ & 100.500 & 20.10 & $\mathrm{~S}$ \\
\hline Colhe Bem & Okra & 5.000 & 5.750 & 1.15 & $\mathrm{~S}$ & 5.600 & 1.12 & $\mathrm{~S}$ \\
\hline Santa Cruz 47 & Okra & 5.000 & 5.150 & 1.03 & $\mathrm{~S}$ & 5.500 & 1.10 & $\mathrm{~S}$ \\
\hline PRO 277 & Cotton & 5.000 & 150 & 0.03 & $\mathrm{R}$ & 150 & 0.03 & $\mathrm{R}$ \\
\hline IAC 29-233 & Cotton & 5.000 & 150 & 0.03 & $\mathrm{R}$ & 100 & 0.02 & $\mathrm{R}$ \\
\hline PR 136 & Cotton & 5.000 & 100 & 0.02 & $\mathrm{R}$ & 100 & 0.02 & $\mathrm{R}$ \\
\hline Vinagreira & Vinagreira & 5.000 & 50 & 0.01 & $\mathrm{R}$ & 0 & 0.00 & $\mathrm{R}$ \\
\hline IAC 24 & Cotton & 5.000 & 100 & 0.02 & $\mathrm{R}$ & 100 & 0.02 & $\mathrm{R}$ \\
\hline IAC 03-979 & Cotton & 5.000 & 0 & 0.00 & $\mathrm{R}$ & 0 & 0.00 & $\mathrm{R}$ \\
\hline
\end{tabular}

UNESP-FCAV: Universidade Estadual Paulista, Faculdade de Ciências Agrárias e Veterinárias, PI: initial population, PF1: final population in the first experiment, PF2: Final population in the second experiment, FR1: reproduction factor in the first experiment, FR2: reproduction factor in the second experiment.

Reaction classes: Resistant (R) and Susceptible (S). 
whereas 'Big Power' only had traces of galls. After two consecutive years of cultivation using the tolerant rootstock, they had suppressed the incidence of crop damage more than that achieved by the application of 1.3-dichloropropene, a standard fumigant. In fact, 'Big Power' reduced the population of nematodes to just 40 juveniles $500 \mathrm{~cm}^{-3}$ soil compared with that of 2500 juveniles $500 \mathrm{~cm}^{-3}$ after using the fumigant (Rivard et al., 2010).

Dropkin and Nelson (1960) reported that resistant cultivars contained nematodes that were less developed than those found in the susceptible cultivars. The resistance to invasion of juvenile nematodes has been attributed to hypersensitivity reactions (Dropkin, 1969). It was also noticed that an increased activity of phenylalanine ammonia-lyase and peroxidase enzymes occurred in the resistant plants after nematode inoculation (Brueske, 1980; Zacheo et al., 1993).

According to work by Hussain et al. (2014), when resistance or susceptibility to nematodes is expressed within a single species of plant, specific genes responsible do not totally suppress the infection. Nevertheless, resistant or nonhost species exhibit a larger suppression of the favorable conditions to parasitism. Various stages of the nematode life cycle may be affected by differences in the conditions for parasitism that the individual host offers: juveniles attacking a resistant plant are unable to penetrate the plant's roots, or may even die after such penetration because of mechanisms preventing their full development or female reproduction.

The differences seen in nematode proliferation rates could be partially due to genetic factors in the host that confer susceptibility or resistance, as well as genetic differences inherent between populations of attacking nematode species (Jacquet et al., 2005; Castagnone-Sereno, 2006).

Comparing FR of the two nematodes species we evaluated, it is evident that $M$. enterolobii is the more aggressive one. It has a high reproduction rate in many host plants known to have resistance to other nematode species, such as $M$. incognita, $M$. javanica, and $M$. arenaria (Kiewnick et al., 2009). For this reason, and not surprisingly, this M.enterolobii is considered as perhaps the most aggressive among the Meloidogyne genus (Rodriguez et al., 2007). Only first reported in Brazil in 2001, in guava plants from Pernambuco and Bahia, M. enterolobii was mistakenly identified at that time as M. mayaguensis (Carneiro et al., 2001).

The cotton and vinagreira tested here were resistant to the two species of nematode, as discussed above, and therefore we suggest that they offer potential rootstocks for okra plants.
The use of grafting in vegetable production systems has expanded considerably as a way to overcome soilborne pathogens and parasites, such as fungi, bacteria, and nematodes (Louws et al., 2010). Several factors triggered the expansion of grafting, namely, the increased density of soil pathogens that result from intensified production practices; ever-greater dependence on susceptible cultivars to meet specific market demands; emergence and spread of new pathogens; increased interest in, and use of organic farming practices; use of protected cultivars; lack of appropriate, affordable technology for farmers with limited resources; and the ban on the use of methyl bromide (Louws et al., 2010).

Regarding the survivorship of grafted plants, we recorded values between $99.4 \%$ and $100.0 \%$. These near-identical values were significantly similar among treatments, even when compared to the self-grafted plants (Table 2). The resistance characteristics evaluated soon after grafting are shown in Table 3; they do not differ significantly except for DPE, where we note that vinagreira had the lowest average, differing from the other rootstocks tested.

Among the rootstocks evaluated $18 \mathrm{~d}$ after grafting, vinagreira had the highest mean values for ALT, NC, and MFE; but among these only ALT differed from self-grafted (Table 3). These values may indicate greater compatibility between grafted parts and longer root system than that provided by cotton plants, which should permit more efficient exploration of the substrate and better maintenance of the physiological needs of the graft. Regarding the cotton genotypes, they had mean values inferior to the self-grafted and vinagreira treatments for ALT, DE, NF, MFT, and MFE resistance characteristics. One explanation for this may be the small root length of these genotypes, or an incomplete compatibility between grafted parts.

Among the tested Malvaceae genotypes, vinagreira showed the best results, with development of a scion similar to that of the self-grafted. By contrast, cotton genotypes did not achieve the same success, with poor scion development. Thus, taxonomic affinity is an important requisite for successful grafting, but in of itself is no guarantee. For example, within the Solanaceae family, grafting between tomato and pepper (Capsicum spp.) plants is strongly incompatible, whereas between tomato and eggplant $(S$. melongena) is moderately compatible when compared to the grafting among genotypes of S. lycopersicum (Kawaguchi et al., 2008).

The success of grafting also depends on genotype compatibility. Based on the results, it appears there was excellent compatibility when gauged by the percentage of

Table 2. Survival of okra plants (\%) grafted onto Malvaceae genotypes. UNESP-FCAV, Jaboticabal, São Paulo, 2015.

\begin{tabular}{lcccccc}
\hline & \multicolumn{3}{c}{ Rootstock } \\
\cline { 2 - 6 } Scion & 'Colhe Bem IAC' & PRO 277 & IAC 29-233 & PR 136 & Vinagreira & IAC 24 \\
\hline 'Colhe Bem IAC' & $100 \mathrm{a}^{1}$ & $99.7 \mathrm{a}$ & $99.4 \mathrm{a}$ & $99.5 \mathrm{a}$ & $99.5 \mathrm{a}$ & $100 \mathrm{a}$ \\
\hline
\end{tabular}

${ }^{1}$ Different lower-case letters indicate significant differences at $\mathrm{p} \leq 0.05$ by the Tukey's test.

UNESP-FCAV: Universidade Estadual Paulista, Faculdade de Ciências Agrárias e Veterinárias. 
Table 3. Plant height (ALT), scion diameter (DE), rootstock diameter (DPE), number of leaves (NF), total fresh weight (MFT), fresh weight of scion (MFE), fresh weight of rootstock (MFPE), fresh weight of roots (MFR), and root length (COMPR) of okra plant 'Colhe Bem IAC' grafted onto Malvaceae genotypes. UNESP-FCAV, Jaboticabal, São Paulo, 2015.

\begin{tabular}{|c|c|c|c|c|c|c|c|c|c|c|c|}
\hline \multirow[b]{3}{*}{ Rootstock } & \multicolumn{11}{|c|}{ 'Colhe Bem IAC' scion } \\
\hline & \multicolumn{3}{|c|}{$0 \mathrm{~d}$} & \multicolumn{8}{|c|}{$18 \mathrm{~d}$} \\
\hline & ALT & $\mathrm{DE}$ & DPE & ALT & $\mathrm{DE}$ & DPE & NF & MFT & MFE & MFPE & MFR \\
\hline & $\mathrm{cm}$ & $\longrightarrow$ & - & $\mathrm{cm}$ & 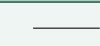 & 1 & & & - & & \\
\hline Self-grafting & $2.81 \mathrm{a}^{1}$ & $1.62 \mathrm{a}$ & $1.97 \mathrm{a}$ & $9.45 \mathrm{a}$ & $1.99 \mathrm{a}$ & $2.58 \mathrm{a}$ & $3.86 \mathrm{a}$ & $3.11 \mathrm{a}$ & $1.47 \mathrm{a}$ & $0.24 b c$ & $1.40 \mathrm{a}$ \\
\hline Vinagreira & $2.73 a$ & $1.55 \mathrm{a}$ & $1.26 \mathrm{~b}$ & $7.10 \mathrm{~b}$ & $2.02 \mathrm{a}$ & $1.64 \mathrm{c}$ & $4.00 \mathrm{a}$ & $2.19 b$ & $1.33 \mathrm{a}$ & $0.10 \mathrm{c}$ & $0.77 \mathrm{~b}$ \\
\hline PRO136 & $2.71 \mathrm{a}$ & $1.61 \mathrm{a}$ & $1.77 \mathrm{a}$ & $3.61 \mathrm{c}$ & $1.75 b$ & $2.02 b c$ & $2.14 \mathrm{~b}$ & $1.60 \mathrm{c}$ & $0.48 b$ & $0.55 \mathrm{a}$ & $0.76 \mathrm{~b}$ \\
\hline IAC20233 & $2.56 \mathrm{a}$ & $1.57 \mathrm{a}$ & $1.78 \mathrm{a}$ & $3.36 \mathrm{c}$ & $1.50 \mathrm{~b}$ & $1.93 b c$ & $2.00 \mathrm{~b}$ & $1.71 b c$ & $0.47 \mathrm{~b}$ & $0.28 b c$ & $0.96 b$ \\
\hline IAC03979 & $2.64 a$ & $1.54 \mathrm{a}$ & $1.90 \mathrm{a}$ & $3.16 \mathrm{c}$ & $1.50 \mathrm{~b}$ & $2.02 b c$ & $2.00 \mathrm{~b}$ & $1.78 b c$ & $0.34 \mathrm{~b}$ & $0.37 \mathrm{ab}$ & $1.08 \mathrm{ab}$ \\
\hline PRO277 & $2.56 \mathrm{a}$ & $1.57 \mathrm{a}$ & $1.73 \mathrm{a}$ & $3.04 \mathrm{c}$ & $1.48 b$ & $2.07 \mathrm{~b}$ & $2.00 \mathrm{~b}$ & $1.65 \mathrm{c}$ & $0.29 b$ & $0.39 \mathrm{ab}$ & $0.79 \mathrm{~b}$ \\
\hline Mean & 2.67 & 1.58 & 1.73 & 4.96 & 1.70 & 2.05 & 2.67 & 2.00 & 0.73 & 0.32 & 0.96 \\
\hline $\mathrm{CV}, \%$ & 11.89 & 12.14 & 11.46 & 15.65 & 11.39 & 11.84 & 12.05 & 15.79 & 22.69 & 22.50 & 23.54 \\
\hline F test & $0.73^{\text {ns }}$ & $3.57^{\mathrm{ns}}$ & $11.12^{* *}$ & $84.10^{* *}$ & $11.80^{* *}$ & $11.14^{* *}$ & $65.17^{* *}$ & $23.23^{* *}$ & $70.52^{* *}$ & $8.78^{* *}$ & $8.58^{* *}$ \\
\hline DMS & 0.51 & 0.31 & 0.32 & 1.24 & 0.31 & 0.38 & 0.51 & 0.54 & 0.26 & 0.21 & 0.36 \\
\hline
\end{tabular}

${ }^{1}$ Different lower-case letters within columns indicate significant differences at $\mathrm{p} \leq 0.05$ by the Tukey's test.

CV: Coefficient of variation. DMS: Significant minimum difference.

${ }^{*},{ }^{* *}$ Significant at the 0.05 and 0.01 probability levels, respectively, by the F Snedecor test.

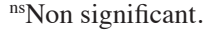

plants surviving (Table 2). Nevertheless, there is yet no precise, objective definition of "graft compatibility"; a graft is often considered to be compatible if the graft union is successful and the grafted plant goes on to live and develop properly (Goldschmidt, 2014). However, in paying closer attention to the plant responses associated with development (Table 3), clearly vinagreira showed greater potential as future rootstock for okra.

Although studies that evaluate genotype compatibility should include homografts as controls (i.e., self-grafts), this requirement is not always fulfilled (Olmstead et al., 2006; Flaishman et al., 2008; Kawaguchi et al., 2008).

Grafting in the cotyledon stage provides good scion survival and facilitates establishment of a better age for successful grafting as younger plants enjoy a greater chance of compatibility. The age difference between graft and rootstock can significantly affect patterns of gene expression and thus interfere with the reproductive development of the plant (Tzarfati et al., 2013). For example, in pepper (Capsicum annuum L.), homografts aged $58 \mathrm{~d}$ showed reduced development when compared with younger grafts (34 d), and grafts in older plants also had a lower percentage of xylem connections and were less tolerant to water stress (Johkan et al., 2009).

The time required for reestablishment of appropriate physiological activities between scion and rootstock depends upon the lignification of the materials to be grafted. In Arabidopsis sp., Yin et al. (2012) found that the functional establishment of the conducting vessels is detectable on the third day after grafting. However, Turnbull (2010), in similar work, claimed that the total lignification of conducting vessels could only occur 7 to $12 \mathrm{~d}$ after grafting.

Goldschmidt (2014) reported that the initial healing of the graft, by itself, does not guarantee long-term compatibility. While incompatibility is a measurement not easily quantified, various degrees of incompatibility can be discerned, ranging from mild abnormalities in the development of the plant to their outright death.

In developing the union between scion and rootstock, substantial changes happen, such as cell differentiation and tissue regeneration. Histological changes in the grafted area may cause mild or serious interference in the functional establishment of grafted parts. A disorder commonly observed is the convolution of the orientation of vascular elements (Flaishman et al., 2008; Kawaguchi et al., 2008). Such changes disrupt the normal flow of endogenous auxin and may be responsible for this distortion (Cano-Delgado et al., 2010). This hypothesis has received empirical support by Yin et al. (2012), who demonstrated the involvement of auxin in the initial stages of the formation of the graft union.

The natural root/shoot interaction is a complex one, and it is further complicated in grafted plants which undergo drastic changes between the injury and healing phases, followed by plant-plant interactions throughout the life-cycle (Goldschmidt, 2014). The binding of xylem determines hydraulic conductivity between root and shoot (Atkinson et al., 2003). Likewise, irregularities in the phloem binding appear to be an important source of incompatibility between plants in the long term.

The pioneering studies of Gur et al. (1968) demonstrated the gradual accumulation of toxic substances in pear trees (Pyrus communis L.) that were grafted onto quince (Cydonia oblonga Mill.) In that case, the cyanogenic glycoside moved from the quince rootstock into the pear shoot, where it was then catabolized enzymatically to releasing cyanide in the graft region. Cyanide, being a harmful substance to the development of tissues, thus affected the graft union, causing cell necrosis, which in turn generated the incompatibility (Gur et al., 1968).

Studies suggest another mechanism of incompatibility, one due to progressive impairment of transport of carbohydrates by the phloem, which in turn generates 
starch accumulation in the area of the graft union. The gradual starch accumulation impairs the metabolism and transport of assimilates between the grafted parts, thereby damaging the development of both plants (Goldschmidt, 2014). These phenomena resemble the damage often caused by girdling (i.e., removal of a ring of bark) or branch of a tree (Goren et al., 2004).

Incompatibility observed between the okra and cotton genotypes require further studies. However, the incompatibility factors mentioned above may be hypothetical explanations of underdevelopment of cotton compared to the vinagreira plants.

Considering the promising compatibility observed between the okra and vinagreira, the adoption of this technique may be possible using robotics, since this can produce many seedlings in a very short time.

\section{CONCLUSION}

Because okra showed great adaptation to grafting by the cleft grafting method, this approach can be added to the technical management of root-knot nematode. Vinagreira and cotton plant genotypes (PRO 277, IAC 29-233, PR 136, IAC 24, and IAC 03-979) are resistant to Meloidogyne enterolobii and $M$. incognita nematodes. However, the $M$. enterolobii is more aggressive in its impact than $M$. incognita. Finally, among the genotypes tested, vinagreira is the best candidate to use as rootstock for okra.

\section{REFERENCES}

Alegbejo, M., Ogunlana, M., and Banwo, O. 2008. Survey for incidence of okra mosaic virus in northern Nigeria and evidence for its transmission by beetles. Spanish Journal of Agricultural Research 6:408-411.

Atkinson, C.J., Else, M.A., Taylor, L., and Dover, C.J. 2003. Root and stem hydraulic conductivity as determinants of growth potential in grafted trees of apple (Malus pumila Mill.) Journal of Experimental Botany 54:1221-1229. doi:10.1093/jxb/erg132.

Begum, N., Haque, M.I., Mukhtar, T., Naqvi, S.M., and Wang, J.F. 2012. Status of bacterial wilt caused by Ralstonia solanacearum in Pakistan. Pakistan Journal of Phytopathology 24:11-20.

Brueske, C.H. 1980. Phenylalanine ammonia-lyase activity in tomato roots infected and resistant to the root-knot nematode, Meloidogyne incognita. Physiological Plant Pathology 16:409414. doi:10.1016/S0048-4059(80)80012-9.

Cano-Delgado, A., Lee, J.Y., and Demura, T. 2010. Regulatory mechanisms for specification and patterning of plant vascular tissues. Annual Review of Cell and Developmental Biology 26:605-637. doi:10.1146/annurev-cellbio-100109-104107.

Carneiro, R.M.D.G., Moreira, W.A., Alves-Almeida, M.R., e Gomes, A.C.M.M. 2001. Primeiro registro de Meloidogyne mayaguensis em goiabeira no Brasil. Nematologia Brasileira 25:223-228.

Castagnone-Sereno, P. 2006. Genetic variability and adaptive evolution in parthenogenetic root-knot nematodes. Heredity 96:282-289. doi:10.1038/sj.hdy.6800794.
Daramola, F.Y., Popoola, J.O., Eni, A.O., and Sulaiman, O. 2015. Characterization of root-knot nematodes (Meloidogyne spp.) associated with Abelmoschus esculentus, Celosia argentea and Corchorus olitorius. Asian Journal of Biological Sciences 8:4250. doi:10.3923/ajbs.2015.42.50.

Dropkin, V.H. 1969. Necrotic reaction of tomatoes and other hosts resistant to Meloidogyne - reversal by temperature. Phytopathology 59:1632.

Dropkin, V.H., and Nelson, P.E. 1960. The histopathology of rootknot nematode infection in soybeans. Phytopathology 50:442-447.

Fallik, E., and Ilic, Z. 2015. Grafted vegetables-the influence of rootstock and scion on postharvest quality. Folia Horticulturae 26:79-90. doi:10.2478/fhort-2014-0008.

Flaishman, M.A., Loginovski, K., Golobowich, S., and LevYadun, S. 2008. Arabidopsis thaliana as model system for graft union development in homografts and heterografts. Journal of Plant Growth Regulation 27:231-239. doi:10.1007/ s00344-008- 9050-y.

Goldschmidt, E.E. 2014. Plant grafting: new mechanisms, evolutionary implications. Frontiers in Plant Science 5:1-9. doi:10.3389/fpls.2014.00727.

Goren, R., Huberman, M., and Goldschmidt, E.E. 2004. Girdling: physiological and horticultural aspects. Horticultural Reviews 30:1-36. doi:10.1002/9780470650837.ch1.

Gur, A., Samish, R.M., and Lifshitz, E. 1968. The role of the cyanogenic glucoside of the quince in the incompatibility between pear cultivars and quince rootstocks. Horticulture Research 8:113-134.

Hussain, M.A., Mukhtar, T., and Kayani, M.Z. 2011. Assessment of the damage caused by Meloidogyne incognita on okra (Abelmoschus esculentus). The Journal of Animal and Plant Sciences 21:857-861.

Hussain, M.A., Mukhtar, T., and Kayani, M.Z. 2014. Characterization of susceptibility and resistance responses to root-knot nematode (Meloidogyne incognita) infection in okra germplasm. Pakistan Journal of Agricultural Sciences 51:319-324.

Hussain, M.A., Mukhtar, T., Kayani, M.Z., Aslam, M.N., and UlHaque, M.I. 2012. A survey of okra (Abelmoschus esculentus) in the Punjab province of Pakistan for the determination of prevalence, incidence and severity of root-knot disease caused by Meloidogyne spp. Pakistan Journal of Botany 44:2071-2075.

ISO Group. 2014. ISO Graft 1200. ISO Group, Gameren, The Netherlands. Available at http://www.isogroepmachinebouw.nl/ en/isograft1200.html (accessed July 2016).

Jacquet, M., Bongiovanni, M., Martinez, M., Verschave, P., Wajnberg, E., and Castagnone-Sereno, P. 2005. Variation in resistance to the root-knot nematode Meloidogyne incognita in tomato genotypes bearing the $M i$ gene. Plant Pathology 54:9399. doi:10.1111/j.1365-3059.2005.01143.x.

Johkan, M., Mitukuri, K., Yamasaki, S., Mori, G., and Oda, M. 2009. Causes of defoliation and low survival rate of grafted sweet pepper plants. Scientia Horticulturae 119:103-107. doi:10.1016/j.scienta.2008.07.015.

Kawaguchi, M., Taji, A., Backhouse, D., and Oda, M. 2008. Anatomy and physiology of graft incompatibility in solanaceous plants. The Journal of Horticultural Science and Biotechnology 83:581-588. doi:10.1080/14620316.2008.11512427.

Kayani, M.Z., Mukhtar, T., Hussain, M.A., and Haque, M.I. 2013. Infestation assessment of root-knot nematodes (Meloidogyne spp.) associated with cucumber in the Pothowar region of Pakistan. Crop Protection 47:49-54. doi:10.1016/ j.cropro.2013.01.005. 
Kiewnick, S., Dessimoz, M., and Franck, L. 2009. Effects of the $\mathrm{Mi}-1$ and the $\mathrm{N}$ root-knot nematode-resistance gene on infection and reproduction of Meloidogyne enterolobii on tomato and pepper cultivars. Journal of Nematology 41:134-139.

Kobayashi, K. 2005. Vegetable grafting robot. Research Journal of Food and Agriculture 28:15-20.

Louws, F.J., Rivard, C.L., and Kubota, C. 2010. Grafting fruiting vegetables to manage soilborne pathogens, foliar pathogens, arthropods and weeds. Scientia Horticulturae 127:127-146. doi:dx.doi.org/10.1016/j.scienta.2010.09.023.

Mohanta, S., and Mohanty, K.C. 2012. Screening of okra germplasms/varieties for resistance against Meloidogyne incognita. Journal of Plant Protection and Environment 9:66-68.

Oliveira, R.D.L., Silva, M.B., Aguiar, N.D.C., Bérgamo, F.L.K., Costa, A.S.V., e Prezotti, L. 2007. Nematofauna associada à cultura do quiabo na região leste de Minas Gerais. Horticultura Brasileira 25:088-093.

Olmstead, M., Lang, N.S., Ewers, F.W., and Owens, S.A. 2006. Xylem vessel anatomy of sweet cherries grafted onto dwarfing and nondwarfing rootstocks. Journal of the American Society for Horticultural Science 131:577-585.

Oostenbrink, M. 1966. Major characteristics of the relation between nematodes and plants. Mededelingen (Landbouwhogeschool Wageningen) 66:1-46.

Rivard, C.L., O'Connell, S., Peet, M.M., and Louws, F.J. 2010. Grafting tomato with interspecific rootstock to manage diseases caused by Sclerotium rolfsii and southern rootknot nematode. Plant Disease 94:1015-1021. doi:dx.doi. org/10.1094/PDIS-94-8-1015.
Rodriguez, M.G., Gómez, L., y Peteira, B. 2007. Meloidogyne mayaguensis Rammah y Hirschmann, plaga emergente para la agricultura tropical y subtropical. Revista Protección Vegetal 22:183-196.

Turnbull, C.G.N. 2010. Grafting as a research tool. Methods in Molecular Biology 655:11-26. doi:10.1007/978-1-60761765-5_2.

Tzarfati, R., Ben-Dor, S., Sela, I., and Goldschmidt, E.E. 2013. Graft-induced changes in microRNA expression patterns in Citrus leaf petioles. Open Plant Science Journal 7:17-23. doi:10. 2174/1874294701307010017.

Yamakawa, K. 1982. Use of rootstocks in solanaceous fruitvegetable production in Japan. Japanese Agricultural Research Quarterly 15:175-179.

Yin, H., Yan, B., Sun, J., Jia, P., Zhang, Z., and Yan, X. 2012. Graft-union development: a delicate process that involves cellcell communication between scion and stock for local auxin accumulation. Journal of Experimental Botany 63:4219-4232. doi: $10.1093 /$ jxb/ers109.

Zacheo, G., Orlando, C., and Bleve-Zacheo, T. 1993. Characterization of anionic peroxidases in tomato isolines infected by Meloidogyne incognita. Journal of Nematology 25:249-256. 